\title{
ПСИХОКРИТИКА: ПРИМЕНА НАУЧНЕ МЕТОДОЛОГИЈЕ У ЛИТЕРАТУРИ
}

\author{
"Чим се роди, човек се најпре сусреће с језиком \\ јер то је нешто ито му је дато. \\ Чак је и пре рођења ухваћен у ту његову мрежу." \\ Жак ЛАКАН
}

\section{Сажетак}

Наука има своју сопствену културну историју а оно што нас посебно инетересује је однос науке и литературе. Научници и њихова открића су често тема литерарних дела а литература је културна област погодна за примену и тестирање неких научних теорија и методологије.

Филозофија, психологија и медицина налазе у литератури могуће доказе неких научних претпоставки. Када се делу приступи научно-методолошки, неопходно је дефинисати предмет анализе. У фокусу могу бити литерарни јунак, прича или сам аутор али и естетски доживљај читаоца.

Француски преводилац Шарл Mоро (Charls Mauron) je творац првог структурираног метода интерпретације литерарног дела применом психоанализе. Овај нови приступ, инспирисан Фројдовом теоријом, настао је 1963. године, а назван је психокритика.

Литерарно дело, било да припада жанру фантастике или реализма, представља субјективни исказ настао из личног искуства писца, а понекад и израз неке органске болести или менталне девијације. Литерарно значење не може бити сасвим објективна категорија јер је и критичар пре свега читалац.

Примена психоаналитичких постулата на ликове и садржај литерарних дела је често индиректни поступак анализе писца који почива на претпоставци да је главни јунак онај с којим се писац идентификује. Фројд (Freud) је на тај начин анализирао Шекспирове јунаке као и главне ликове у романима Достојевског.

Француски психоаналитичар, Жак Лакан (Jacques Lacan), аутор бројних радова из области психоанализе и литерарне теорије, користио је литерарне примере као илустрације својих теоријских концепата. Лакан је дао значајан допринос 
литерарној психокритици тиме што је пажњу преместио са анализе аутора на лингвистичке елементе текста. Лакан се концентрише на језик, стил, употребљене фигуре управо са циљем да препозна бројне изразе који метафорично описују један исти афекат. Он сматра фантазам литерарним елементом који се односи на целокупни литерарни сценослед. Психоаналитичарка Колет Солер (Colette Soler) слаже се са Лакановим привилеговањем језика и истиче да је препознавање емоција могуће једино ако се оне јасно именују.

Поред психоаналитичара и лингвиста, многи лекари су се бавили анализом литературе у покушају индиректне дијагностике болести писца. Анализиран је Шекспиров рукопис као могућа последица органске болести, халуцинације и депресија Вирџиније Вулф, меланхолија као последица туберкулозе код многих великих писаца а спроведена је и студија о могућности препознавања раних знакова деменције писца у његовом делу.

Психокритика подразумева и неку врсту генерализације путем које је могуће разумевање културне средине у којој ствара писац или оне коју описује у свом делу. Психоаналитички метод ипак остаје најпогоднији структурни метод који обликује психокритички дискурс.

Кључне речи: научно-методолошки приступ, психокритика, литерарно значење као субјективна категорија, Лаканова лингвистичка психокритика, фантазам као литерарни термин, индиректна медицинска дијагностика болести писца

\section{УвоД}

Дела из области културе и наука имају заједничку основну претпоставку а то је креативност творца дела. Без науке нема економског просперитета друштва а култура долази на врх пирамиде као врста луксуза оних који имају задовољене основне потребе, док се културни производи као неки бумеранг враћају на дно лествице да би још брже подстакли развој друштва.

Наука има своју културну историју, своје успоне и падове, има своје фазе убрзаног развоја природних наука и открића која померају границе сазнања, управо у неким посебним културним срединама или културно-историјским околностима. Ту су и друштвене науке које се константно баве културом, обрасцима понашања и утицајем историјског момента на обликовање културе као и утицајем производа културе на токове друштва и историје.

Посебно је занимљив однос науке и литературе. Велика научна открића и знаменити научници су честа тема или инспирација ли- 
Култура и/или наука

терарних дела, пре свега биографске литературе. Бројна су питања и честе потраге за правим одговорима, а нека од најчешћих су:

- како је живео и како се образовао научник који је обележио будућност човечанства;

- у ком историјском моменту долази до појаве већег броја великих уметника, сликара, писаца или научника;

- у којим деловима и земљама света је подстицан развој науке а где су настајала најинспиративнија дела културе и уметности?

\section{Зашто је литература погодна за примену научне теорије}

Литература је погодно место за примену и проверу одређене научне теорије или методологије јер су речи одређеније и мање подложне субјективном тумачењу од других уметничких средстава и дела као што су, на пример, слике или архитектонске грађевине. Филозофија, као претеча свих наука и психологија, настала као модерна природна наука али данас обогаћена и бројним друштвеним дисциплинама, су две науке које често у литерарној фикцији налазе свој израз и доказе за своје научне претпоставке.

Посебан психолошко-критички приступ делу је онај који на прво место ставља субјективни доживљај дела и емоционални одговор на естетски и уметнички доживљај читаоца. Када се делу приступи научно-методолошки, неопходно је дефинисати предмет посматрања и анализе. То може бити сама књижевна грађа а првенствено ликови, карактери и прича. У фокусу може бити и сам аутор, творац мање или више фиктивног света, или сам естетски доживљај који описују читаоци дела. Уобичајена психолошка претпоставка јесте да свет који креира писац симболично представља његове потиснуте, заборављене или несвесне садржаје. Управо су те дочаране слике и скривена значења оно што комуницира са читаоцем у чијем разумевању грађе играју важну улогу и његови несвесни садржаји.

Француски преводилац енглеске литературе и литерарни критичар, Шарл Моро (Charls Mauron) творац је првог структурираног метода интерпретације литерарног дела применом психоанализе. Он је тај нови приступ, инспирисан Фројдовом теоријом, настао 1963. године, назвао психокритицизам или психокритика. 
"То је термин који се односи на две врсте анализе: једна је усмерена на откривање латентног, несвесног значења неке песме или другог литерарног дела а друга на боље разумевање начина на који функционише машта писца." (Crickshank, 1964 :155)

Овај приступ литерарној критици заснива се на претпоставци да је креативни процес налик сну будног човека. То је нека врста несвесног процеса, представе или импулса који се најбоље исказује путем симбола и метафора. Критичар се оријентише на анализу симболичких тема и скуп метафора у делу, које означавају и описују латентну реалност пишчевог унутрашњег света. Пишчева литерарна креација се доводи у вези са његовим личним животом или карактеристикама личности. Обраћа се пажња на његове болести, трауме, културне архетипове. Његово дело се посматра као сублимација његових потиснутих односно несвесних импулса.

\section{Објективност литерарног значења}

Када нам неко исприча нешто што нас подсећа на нас саме, ми се идентификујемо са тим, иако свесни да је у питању фиктивни садржај и имамо осећај да смо поново открили или разоткрили још један део себе. Да би све ово било могуће, постоје предуслови. Основни услов је језик и разумевање значења речи, што је процес који се одвија и на интелектуалном и на емоционалном нивоу.

Најважнији је део процеса у којем се препознаје и интројектује садржај и сви елементи фантазије или фиктивне стварности о којој пише аутор. Овај ниво разумевања је врло сличан процесу интројекције доброг и лошег објекта, о чему је писала британска психоаналитичарка Меланија Клајн (Melanie Klein). Она објашњава да је цепање објекта који се интројектује на добар и лош аспект, заштитни механизам јер има за циљ да у себи сачува слику и доживљај доброг а одстрани онај лош аспект који ствара анксиозност. (Klein, 1975: 324)

Из животног искуства знамо да се нешто слично дешава и са нашим успоменама из којих временом нестају негативни детаљи а слика која остаје у сећању све више личи на идеалну. Задовољство од интројекције доброг објекта није само кратктотрајно већ је од почетка испуњено тензијом због могућности губитка. Та несигурност 
Култура и/или наука

и негативна тензија је стално присутна. Сваки објекат који пружа задовољство садржи у себи претњу од губитка. (Swiatkowsky, 2015: 46) Речено језиком народне мудрости: Све што је лепо, кратко траје!

Наше првобитне фантазије накнадним личним животним искуством бивају обогаћене, дорађене и интерпретиране али су у основи веома сличне код свих појединаца. Да није тако, сви туђи садржаји би за нас били некомуникативни. Значење неког дела је врста конструкта и оно обухвата и свесни и несвесни ниво. Могуће је да неко дело додирне емоције читаоца иако писац није ни хтео да каже оно што је читалац разумео. То се одвија помоћу речи које могу бити у самом том делу сасвим споредне и небитне, али за читаоца су то битне речи које он издваја, апстрахује, јер побуђују асоцијације и он их доживљава као важне и пуне личног значења. То нам говори да литерарно значење не може бити сасвим објективна категорија јер је и критичар пре свега читалац.

\section{Субјективност литерарног дела}

Литерарно дело, ма колико било фикције у њему, представља субјективни исказ, настао из личног искуства аутора, а понекад је оно и израз неке органске болести или менталне девијације. Било је више покушаја да се анализирају личност и здравље писца кроз његово дело или опус. Тако је, на пример, дело Достојевског понекад посматрано у светлу објашњења епилептоидне личности.

Његово најчешће анализирано дело је роман Злочин и казна. Оно обилује сликовитим дескрипцијама стања које је последица осећања кривице али и филозофско - егзистенцијалним питањима. Кад је реч о анализи лика Раскољникова у овом делу, Фројд (S. Freud) “сматра да психоаналитичар мора ићи и даље од очигледног, мора открити шта значе симптоми болести или неуротичног стања главног јунака, који инстинкти су прикривени иза тих симптома и кроз њих задовољени као и какав је то мистериозни пут који води од инстинктивних жеља до симптома“. (Freud, 1997:151)

Психоаналитичар не разматра само окружење и околности злочина описаног у овом роману већ пре свега неуротичне карактеристике злочинца. Такође се његов карактер мора анализирати 
у цивилизацијском контексту и ту се прелази на шире филозофско поље. Док јунак романа протестује због ограничења слобода, Фројд, као да баш лично, Раскољникову, одговара, пише:

„Слобода појединца није цивилизацијски поклон...Развој цивилизације поставља забране а правда налаже да их нико не сме мимоићи." (Freud, 1989: 741)

Раскољников, можда баш у име самог писца, исказује протест. Он нигде не иде, ништа не ради већ само лежи и то је његова побуна против ланца забрана којима је цивилизација оковала човека.

Најверодостојнија и најзанимљивија је примена психоаналитичких постулата на ликове и садржај литерарних дела. То је индиректни поступак анализе творца тог дела која почива на претпоставци да је главни јунак онај с којим се писац идентификује.

И сам Фројд је анализирао Шекспировог Хамлета као одраз и приказ Едиповог комплекса самог аутора. Фројдов ученик и биограф, Ернест Џоунс (Ernest Jones), у својој интерпретацији Хамлетовог комплекса, примећује да је Шекспир писао Хамлета након очеве смрти и да је тај подсвесни ниво закорачио у породичне односе и тиме инспирисао писца да обради велике теме смрти и сексуалности у породичном миљеу. (Jones, 1968: 264)

Фројдова претпоставка о нагонима живота и смрти, о Едиповом комплексу и раном психолошком развоју у породичном троуглу, затим Јунгова теорија архетипова као и фантазије и фантазми у метапсихолошкој британској теорији, налазе више посредних доказа и одличних примера у књижевним делима него у искуствима из ординација бројних психотерапеута. Разлог лежи у чињеници да су та дела израз маште и да речи од којих су саздана нису увек свесно контролисане и конструисане. Постоји нешто што измиче и самом писцу а то је потреба да сублимише неке своје несвесне садржаје и заборављена искуства. Као што у сновима наш разум није сасвим будан, тако и у креативном процесу, он уступа место спонтаним идејама.

У једном од својих најранијих предавања одржаном 1907. године под називом “Креативни писци и сањарење (Freud, 1995: 436-443), Фројд (Freud) се осврнуо на тада популарне романописце, романтике. По Фројду, писац је неуротични егоиста и он пише своје дело као неку врсту поверљивог признања. Његово дело делује терапеутски, и на писца самог и на читаоца јер обезбеђује смањење напетости без икак- 
Култура и/или наука

вих последица и казни. Структура литерарног дела је слична структури снова. Машта је та која обликује слике, представе. Ту има сажимања и померања а логичке и узрочно-последичне везе нису обавезне.

„Постоји нешто што повезује дневно сањарење и уметничко дело. Протагониста дела је обично нерањиви херој, представник Његовог величанства по имену Его, а исти је случај и са дневним сањарењем... Снажно искуство садашњице буди сећање из раног детињства из чега настаје жеља која налази задовољење у креативном раду...Могуће је и да митови представљају фантазију целе нације, неку врсту испуњења световних снова младог човечанства." (Person, 2013: XI)

\section{Лакан: лингвистички елеменати текста}

Чувени француски психоаналитичар, Жак Лакан (Jacques Lacan), аутор је бројних радова из области психоанализе, филозофије и литерарне теорије. Радо је користио литерарне примере као илустрације својих теоријских концепата. Лакан је дао значајан допринос литерарној психокритици тиме што је пажњу преместио са анализе аутора на лингвистичке елементе текста. Сматрао је да Несвесно не функционише на нивоу симбола или на нивоу инстинкта већ лингвистички. Несвесно само по себи не би могло да нађе разумљив и комуникативан израз и да функционише у стварности без посредовања речи. По њему је и само Несвесно један посебан Језик.

"Ако на научни начин претражимо литературу, уочићемо основни проблем психоанализе који се састоји у томе да функцију фантазије психоаналитичари испитују код деце на превербалном нивоу..." (Lacan, 1968: 4)

Лакан се овде пита: а где је ту језик? Он је иначе сматран за аналитичара који занемарује осећања а језику даје предност у сваком контексту. Лакан се концентрише на језик, избор израза, стил, употребљене фигуре управо са намером да дефинише одређене емоције односно препозна бројне изразе који сликовито и метафорично описују један исти афекат.

Психоаналитичарка Колет Солер (Colette Soler) слаже се са Лакановим привилеговањем језика и сматра да је препознавање емоција могуће једино ако се оне јасно именују. 
Без језика и дискурса не бисмо јасно знали шта осећамо, јер дискурс, именујући афекат, заправо успева да га изолује из једног магловитог проживљеног искуства..Па зар се не каже лепо да се нико никада не би заљубио да није чуо људе како причају о љубави!..Језик држи ствари под контролом производећи језичку констелацију у којој има много израза за једно стање или осећање а често су баш песници одговорни за то проширивање и клизање речника." (Солер, 2016: 2-6)

Мексичка песникиња и психоаналитичарка Кармен Виљоро Руиз (Carmen Villoro Ruiz), у свом есеју о фантазму, објашњава разлику употребе овог термина код Фројда, Меланије Клајн и Лакана.

„Код Фројда је израз фантазија сличан дневном сањарењу а несвесне фантазије се разоткривају у сликама из снова као знак нечега што не видимо јер је било потиснуто, као присуство неког одсуства или литерарна метафора. Меланија Клајн несвесне фантазије сматра физичким представницима нагона. Свесну фантазију која је елаборирана, Клајнова пише са словом Ф (fantasy) док несвесне фантазије сматра сировим архаичним сликама и пише их мало друкчије: phantasy.

У Лакановој теорији, фантазам (phantasm) је литерарни термин а литерарни фантазам има карактеристике, не обичне фигуре, већ целог литерарног скрипта са описом сцене... несвесни ток радње који носимо у џепу као што се носи амајлија против зле среће.." (Villoro Ruiz, 2015: 2)

Колико је за Лакана (Lacan) важан језик и његове стилске фигуре, када говори о Несвесном, видимо из једне од његових дефиниција метафоре:

“ Метафора је једна од две фундаменталне фасете игре коју игра Несвесно." (Lacan, 2002: 890)

\section{Медицинска дијагностика писца посредством анализе његовог дела}

Поред психоаналитичара, психолингвиста и психијатара, и припадници других грана медицинске науке су се бавили анализом литерарних дела у покушају индиректне дијагностике болести и патолошких стања аутора. 
Култура и/или наука

\section{Шекспир}

Професор медицине на Харвард Универзитету, Џон Рoc (Ross, John J.), пише о могућим медицинским узроцима дрхтавог Шекспировог рукописа, разматрајући болест сифилис као могући узрок. Рос истражује референце на венеричне болести и сифилис у његовом делу. Поред тога што Шекспир даје веома тачан клинички опис ове болести, “...референце на сифилис су различито распоређене у његовим драмским комадима. У првих 14 драма све до Венецијанског трговца 1596. године, у просеку су по драми присутна само три реда на ову тему. У следећих 20 драма све до 1609. године су присутна 23 реда на ову тему док у последње 4 драме има само по 2 реда." ( Ross, 2012: 6)

Poc (Ross) слободно претпоставља да ове бројке могу бити повезане са појавом болести у средини пишчеве каријере али се ипак ограђује од својих опсервација јер ауторов интерес за сифилис као тему не значи да је он лично био болестан. Сматра ипак да је Шекспиров животни стил и време у којем је живео, свакако био ризик за обољевање. „Али у Шекспировим сонетима чести су изрази као грех, инфекција а срамота се појављује 14 пута...У 144. сонету он пише о пристојном човеку који ће бити полно заражен женским злом...Шекспир користи ироничну метафору за гонореју, називајући је Купидоновомм ватром..." (Ross, 2012: 10)

Од 1495. године се сифилис појавио као нова болест у Европи па је то само можда инспирисало великог писца као појава а не садржај личног искуства.

\section{Халуцинације}

Још један доктор, Оливер Сакс (Oliver Sacks), британски неуролог који је живео и радио у Америци и био предавач на Њујоршкој школи медицине, показао је интерес за живот и посебно за дело пацијента, колико и за саму болест. Он пише о халуцинацијама и псеудохалуцинацијама које се јављају у полубудном стању. Овај феномен га интересује јер су халуцинације, по његовом мишљењу, често богат извор инспирације. “Оне садрже сву креативност маште, снова или фантазије а живе детаље чулне перцепције екстернализују." (Sacks, 2013: XIII) 
Сакс (Sacks) се интересује за халуцинације код органских психоза, епилепсије, делиријума и сл. а не толико за оне код душевних болести. У многим древним културама су халуцинације сматране привилегованим стањем свести. Овог доктора посебно интересују халуцинације које садрже слова, речи, музичке ноте и сличне знакове. Текстовне халуцинације понекад знају бити бесмислене или пак на језику који пацијент у будном стању не познаје. (Sacks, 2013: 12-13)

Када се помињу болести познатих писаца, често је и присећање на енглеску списатељицу, Вирџинију Вулф, која је патила од маничнодепресивне психозе са халуцинацијама.

\section{Ајрис Мардок}

Професор неурологије на Универзитету у Лондону, др Питер Гарард (Peter Garrard), који се бави деменцијом, посветио се анализи језика британске списатељице и филозофа, Ајрис Мардок, на ране знаке Алцхајмерове болести. Он је пошао од хипотезе да пажљивом анализом језика могу да се уоче когнитивна оштећења много пре него што она постану очигледна околини. Поред медицине, др Гарард је студирао и литературу на Оксфорду, и то у време када је установљена дисциплина компјутерске лингвистичке анализе. Како Алцхајмерова болест погађа ћелије управо оних делова мозга који су одговорни за примену и разумевање језика, језичка анализа је погодна за анализу развоја ове врсте патологије. (Garrard, 2015: 128)

“Мардокова је имала 76 година када јој је дијагностикована Алцхајмерова болест а то је било недуго пошто је објавила свој последњи роман, Џексонова дилема. Стога је логична претпоставка да би рани знаци оштећења морали бити видљиви у том делу. Иначе ова болест нарушава семантички систем и ствара сметње у запамћивању имена." (Garrard, 2015: 251)

Ова списатељица је била добитница Букерове награде за роман „Море“ док њен последњи роман није толико одушевио публику. Изведено је компаративно истраживање њеног првог и последњег дела, „Испод мреже“ и „Џексонова дилема“ али и награђеног дела „Море“. (Garrard, 2015: 253)

Коришћен је дигитални програм препознавања карактера. Пажња је усмерена на директни говор и дијалоге. Као резултат су добијене ли- 
сте коришћених речи, поређаних азбучним редом. Коришћени су и случајни узорци од по 100 речи из сваке од књига. Анализиране су сличности и разлике структуре речника, синтаксе и лексичких карактеристика. Резултати су показали да је роман „Море“ сличнији последњем него првом делу. Постоје разлике у општем броју врста употребљених речи. Најмањи је број врста речи у последњем роману а највећи у награђеном који је настао на средини каријере. Присутно је обогаћење речника између првог и средњег романа. Синтаксичка анализа није донела сасвим јасне резултате. Углавном није било значајних разлика између наведене 3 књиге. За анализу лексике, коришћено је по 5 узорака речи за сваку књигу. На последњем роману се показало да је оштећење темпоралног неокортекса коинцидирало са оштећењем лингвистичких способности приказаних у делу, због чега је роман био предмет разозарења код критичара. Реч је о нивоу речника и лексичкој селекцији, пре свега коришћењу мањег броја врста речи. Роман „Џексонова дилема“ је синтаксички најмање комплексан. Налаз упућује да речник мањег обима са чешће коришћеним истим речима али релативно непромењене синтаксичке структуре, указује на доминантно темпоралну патологију и тиме на почетак Алцхајмерове болести. Како иста није примећена дуго после тога, може се закључити и да интелектуални ангажман и квалитет живота одлажу развој ове болести. Код ове болести лексичке грешке доминирају над граматичким. Граматички коректан говор и писање је више аутоматско него што је последица лексичке селекције. Ово је тешко доказати на писаном тексту романа због тога што он пре објављивања пролази лектуру и поправке. Уопштено, очекиване разлике су биле на нивоу лексичких фреквенција али не и дужине речи, семантичке али не и синтаксичке промене мера. Разноврсност речника и ниво уношења нових речи су најнижи код последњег а највиши код средњег романа. (Garrard, 2015: 253-260)

\section{Туберкулоза}

Постоји мишљење и да је туберкулоза, једно време веома распрострањена болест, давала посебан меланхолични тон делима оболелих. Међу њима су Чехов, Кафка, Горки, Молијер а код нас: Ђура Јакшић, Лаза Лазаревић, Милован Глишић. 
Иако су медицинске анализе литерарних дела усмерене на органске болести појединих аутора, најчешће се све на крају своди на њихове психичке поремећаје или стања, јер кашаљ, на пример, није тај који подстиче на стварање већ је то субјективно осећање, психолошко стање, потреба да се надиђе болест или потиштеност услед болести, или да се опишу халуциногена стања каква читалац не може да види у објективној стварности већ само у сопственом искуству или у литерарним делима која потичу из искуства ствараоца.

\section{ЗАКЉУЧАК}

Ма колико научни приступ литерарном делу тежио примени објективних метода, квантитавних мера и показатеља, за анализу уметничког дела је најприкладнији квалитативни метод анализе. Повезивање психологије и литературе даје допринос научном аспекту литерарне критике. Прву и најширу примену у психокритици је нашла психоаналитичка теорија јер су речи као симболи најближи несвесним садржајима, поривима, представама и потребама. Фројд је сматрао да друштво каналише несвесне импулсе кроз креативне процесе. Психоаналитичке теорије су засноване претежно на хипотетским конструктима које је згодно тестирати на примерима из литературе. Психологија и уметност једна другу инспиришу и објашњавају. Литерарно дело се посматра као полуструктуриран пројективни психолошки тест који се служи речима а оне нису увек под савршеном контролом интелекта јер буде осећања и сећања. Психокритика укључује још и когнитивни и естетски приступ литератури. Први се бави размишљањем о радњи, ситуацији и објективним друштвеним околностима које окружују литерарну причу, а други реакцијом читаоца на прочитани текст. Док психолошки приступ анализира садржај, главне јунаке, причу или самог аутора литерарног дела, шира област медицинске анализе усмерена је на писца посредством његовог дела али и познатих података из његове биографије. Психокритика подразумева и неку врсту генерализације путем које је могуће разумевање културе и друштва из којег писац потиче а што је често, директно или посредно, описано у његовом делу. Психоаналитички метод ипак 
остаје најпогоднији структурни метод који обликује психокритички дискурс. Чак и литерарна критика која нема научне претензије често залази на ово научно поље макар само при покушају разумевања основне мотивације главних ликова.

\section{Лumepamypa}

Crickshank, John. 1964. "Psychocriticism and Literary Judgement". article in Brit J Aestetics.

Freud, Sigmund. 1997. "Some Character-Types Met with in Psycho-analytic Work." Writings On Art and Literature. Ed. James Strachey. Stanford: Stanford UP.

Freud, Sigmund. 1989. "Civilizations and Its Discontents." The Freud Reader. Ed. Peter Gay. New York: W.W. Norton \& Company.

Garrard, Peter. et Al. 2005. "The Effects of very early Alzheimer's disease on the characteristics of writing by a renowned author". Brain.

Jones, Ernest. 1968. "Hamlet and Oedipus". in Bevington, David Twentieth Century Interpretations of Hamlet. New Jersey: Prentice Hall.

Klein, Melanie. 1975. Envy and Gratitude and other works. New York: FP-A Division of McMillan

Lacan, Jacques. 1968. The Language of The Self:The Function of Language in Psychoanalysis. Baltimore, Maryland: The Johns Hopkins University Press

Lacan, Jacques. 2002. Ecrits. W.W. New York: Northon\&Company

Person, Ethel Spector and Fonagy, Peter. 2013. On Freud's Creative Writers and Daydreaming. London: Karnac books

Ross, John J. 2012. Shakespeare's tremor and Orwell's cough. New York: St. Martin's Press

Sacks, Oliver. 2013. Hallucinations. New York: First Vintage Books

Soler, Colette. 2016. Lacanian Affects. New York: Routledge

Swiatkowsky, Piotrek. 2015. Deleuze and Desire: Analysis of The Logic of Sense. Leuven, Belgium: Leuven University Press

Villoro Ruiz, Carmen. 2015. The Phantasm: "From Narrative to Poetic Experience" article in Psychoanalysis Today. 


\section{Jelena Radović Jovanović}

Radio Television Serbia

\section{PSYCHOCRITICISM: SCIENTIFIC METHODOLOGY APPLIED TO LITERATURE}

\section{Summary}

Scientists and their discoveries are not rare literary topics and literature is a great cultural field suitable for applying some of the scientific theories and methodology. Philosophy, Psychology and Medicine find in literature some evidence for scientific hypotheses. If we approach to literature scintifically, we must define the object of analysis. It could be one fictional character, the author himself or the reader's aestetic response.

The French translator, Charles Mauron, in 1963 introduced the first structured method for interpreting literature through psychoanalysis. This method, inspired by Freudian theory, is called Psychocriticism. Literary work, weather fictional or realistic in genre, always presents the writer's subjective statement derived from his experience but sometimes it could be the expression of some organic disease or mental state.

The literary meaning is never an objective category because the critic is also the reader. In many cases, applying psychoanalysis to characters and literary content is just the way to analyze the writer which is based on presumption that the writer feels identified with the main character. It was the way Freud analyzed characters from Shakespeare's dramas and novels of Dostoevsky.

Jacques Lacan, a French psychoanalist and the author of numerous works in Psychoanalysis and Theory of Literature, used literary examples as ilustrations of his theoretical concept. Lacan gave a significant contribution to literary psychocriticism by removing focus from analysis of the author to linguistic text elements. Lacan concentrated on Language, Style and Figures in order to recognize different expressions and metaphors describing the same affect. He considered phantasm to be a literary element referring to literary script. Colette Soler, the psychoanalist, agrees with Lacan's language privileging. In her opinion, the recognition of emotions is possible only if they are clearly named.

Many medical doctors also analyzed literature trying to indirectly diagnose the writer's disease. Shakespeare's handwriting was analysed for some organic disease, literary works of Virginia Wolf for halucinations and depression, some writers who suffered from tuberculosis for melancholy felt in their writings and one study on recognising early signs of writer's demention in his literary work.

Psychocriticism sometimes includes some sort of generalization that makes it possible to understand the writer's culture or the one he describes in his literature. Psychoanalytic approach is still the most convenient structural method to shape the discourse of Psychocriticism.

Key words: Psychocriticism, Literar meaning as subjective category, Linguistic Psychocriticism by Lacan, Phantasm as literary expression, Indirect medical diagnosing of writer's disease 